\title{
A different view from the sea: placenaming on Cape Breton Island
}

\author{
William Davey \\ Cape Breton University \\ Sydney NS \\ Canada \\ Bill_Davey@cbu.ca
}

\begin{abstract}
George Story's paper A view from the sea: Newfoundland place-naming suggests that there are other, complementary methods of collection and analysis than those used by his colleague E. R. Seary. Story examines the wealth of material found in travel accounts and the knowledge of fishers. This paper takes a different view from the sea as it considers the development of Cape Breton placenames using cartographic evidence from several influential historic maps from 1632 to 1878 . The paper's focus is on the shift names that were first given to water and coastal features and later shifted to designate settlements. As the seasonal fishing stations became permanent settlements, these new communities retained the names originally given to water and coastal features, so, for example, Glace Bay names a town and bay. By the 1870 s, shift names account for a little more than $80 \%$ of the community names recorded on the Cape Breton county maps in the Atlas of the Maritime Provinces. Other patterns of naming also reflect a view from the sea. Landmarks and boundary markers appear on early maps and are consistently repeated, and perimeter naming occurs along the seacoasts, lakes, and rivers. This view from the sea is a distinctive quality of the island's names.
\end{abstract}

Keywords: Canada, Cape Breton, historical cartography, island toponymy, placenames

(C) 2016 - Institute of Island Studies, University of Prince Edward Island, Canada

\section{Introduction}

George Story's paper The view from the sea: Newfoundland place-naming "suggests other complementary methods of collection and analysis" (1990, p. 41) than those used by his colleague E. R. Seary in his studies of Newfoundland toponymy. Story examines travel accounts and fishers' knowledge of shoals and fishing areas to illustrate the wealth of toponymic information in these sources. This paper takes a different view from the sea as it considers the development of Cape Breton placenames using cartographic evidence from historic maps from the sixteenth to the nineteenth centuries. This nautical perspective is especially evident in the frequent use of shift names. This type of name is originally assigned to one feature and then later applied to a nearby or associated feature and may occur in three forms. ${ }^{1}$ The entire name may be reapplied as occurs with the example of Christmas Island,

\footnotetext{
${ }^{1}$ George Stewart defines the term more technically as "when a specific applied to a particular generic is shifted by association to another, nearby, generic. Thus from an original Deer Creek may come Deer Mountain” (1970, p. xxxi; emphasis in original). He distinguishes a shift name from a transfer name that "is applied in a broad sense to denote names which have been moved from one location to another, e.g. Cambridge, from England to Massachusetts" (ibid.). "Shift names are those derived from the names of other features nearby" (Rayburn, 1973,
} 


\section{W. Davey}

which identifies both an island and a community on the adjacent shore. In other instances, the specific may shift without the original generic as seen in Sydney Harbour and the community of Sydney, or a specific may be applied to other generics such as Sydney shifting to Sydney Forks, Sydney Mines, and Sydney River. In addition to shift names, this centuries-old view from the sea has also influenced the assignment of names that assist navigation and the fishery. Thus, names for sheltered harbours, boundary markers, landmarks, and fishing grounds appear early and persist on subsequent maps. This idea is explored using evidence from several influential historic maps of Cape Breton Island that demonstrate how this view from the sea and inland water features has influenced naming on Cape Breton Island. This practice is not unique to Cape Breton, but reflects a distinctive regional feature of Atlantic toponymy. A modern representation of Cape Breton Island is given in Figure 1.

\section{Figure 1: Cape Breton Island.}

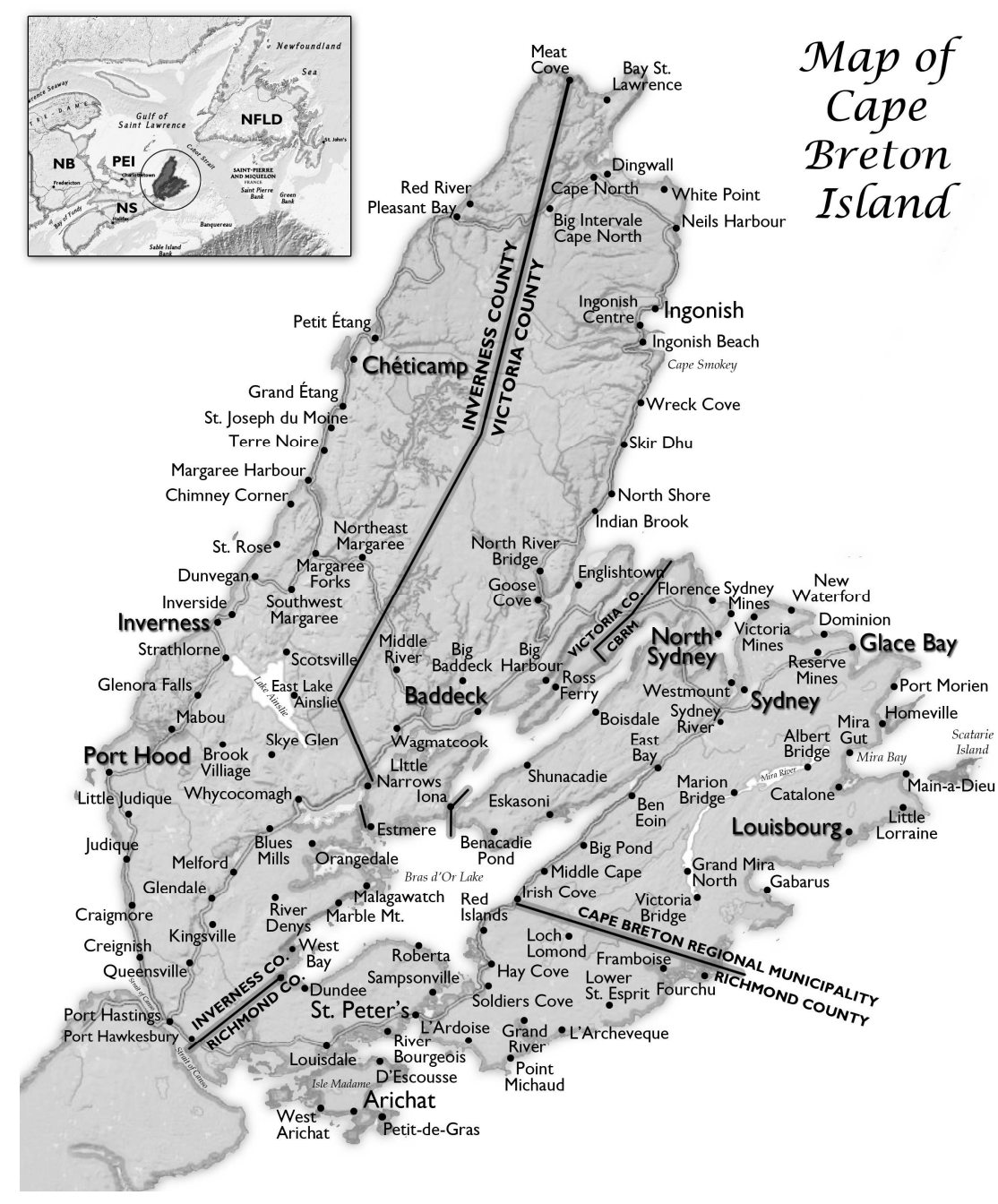

Source: () 2016 - Centre for Cape Breton Studies, Cape Breton University.

p. 10). A shift name is also known as an associative name, "one derived from a nearby place ... Thamesford and Thamesville (from the Thames River)" (Rayburn, 1997, p. xvi). 


\section{Sixteenth and Seventeenth Centuries}

Although Giovanni Cabota (John Cabot) was not the first to discover the lucrative cod fishery on the Grand Banks, ${ }^{2}$ after his announcement of the abundant fish stocks in the New World, Atlantic Canada became the destination of fishers from several western European countries. As the historical geographer Andrew Hill Clark states, during the sixteenth and seventeenth centuries, the coast of Cape Breton Island "was an international haven for drying fish, for a shore-based boat fishery, and for obtaining supplies of wood, coal, or water" (1968, p. 268). The earliest cartographic record of this European view from the sea comes from a Portuguese map from about 1521 (Ganong, 1964, p. 56; Seary, 1971, p. 303). The name C. DOS BRETOES was applied to the most eastern point of Cape Breton's mainland. Like Cape Race on the southeastern corner of Newfoundland, this cape became a boundary maker for ships arriving from Europe. These eastern markers were especially important as navigators had difficulty determining longitude accurately until the mid-eighteenth century. ${ }^{3}$ Consequently, despite the cape's modest size and the fact that the nearby Scatarie Island is farther east, the name Cape Breton with variant spellings began to appear with increasing regularity on maps of the North Atlantic coast. Sebastien Münster's map of North and South America, published in 1540 (Lemon, 1987, p. 35), provides a striking example of eastern boundary markers: $C$. Britonum and Terra florida are the only two placenames given for the Atlantic coast (here and below, the spelling and capitalization of cartographic names reflect that of the original). By the end of the sixteenth century, the name Cape Breton was typically assigned to both the cape and the island itself (Clark, 1968, p. 265). As such, it is the first of many shift names on the island that were first applied to one feature (often a water or coastal feature) and then transferred to another.

The most accurate maps of Cape Breton Island from the early seventeenth century come from the cartography of Samuel de Champlain, especially from his Voyages ... published in 1613 and 1632 (Champlain, 1936). David Hackett Fischer summarizes the appreciation of Champlain's mapping: "His many maps and charts set a new standard for accuracy and detail. Experts have studied them with amazement. They wonder how he made maps of such excellence with the crude instruments at his command" (2008, p. 5). The view from the sea is evident as the offshore fishing banks are outlined and named, and all the toponyms for Cape

\footnotetext{
${ }^{2}$ Marc Lescarbot gives one example of fishing in the sixteenth century. Writing in the early 1600 s, he describes meeting Captain Savalet who had been traveling to the cod banks for forty-two years: "Finally, we arrived within four leagues of Canso [near Cape Breton Island], at a harbour where a fine old sailor from St. Jean de Luz, named Captain Savalet, was fishing ... This worthy man told us that that voyage was his forty-second to these parts, and one must remember that these Newfoundlanders make but one a year" (1911, vol. 2, p. 362). Since St. Jean de Luz is a port in Basque Country, presumably Savalet was one of the early Basque sailors, who came to fish and gather oil from whales and walruses.

${ }^{3}$ The difficulties determining longitude at sea are discussed by Thomson (1966, pp. 10-25), Donovan (1984), and Lemon (1987, p. 20). Morrison's papers graphically illustrate how some of the eighteenth-century maps represent the coastlines fairly accurately, but struggle with the correct longitude. He notes the maps of Joseph Bernard de Chabert and J. F. W. DesBarres are more accurate than others (1975; 1982). Morrison explains: “Cape Breton's longitude shifted back and forth as much as twenty degrees from map to map, because some charts were based on Paris, some on London, and some on Ferro in the Canary Islands" (1990, p. 111). Despite Champlain's important contribution to eastern North American mapping and nomenclature, his famous 1632 map (1936, vol. 6) has two meridians: "The worst error is that the Atlantic coast from Cape Breton to Chesapeake Bay is on a prime meridian different from the rest of the map, with the result that this entire coastline is placed too close to the St. Lawrence River and Great Lakes area” (Heidenreich and Dahl, 2004a, p. 321).
} 
Breton are navigational aids or connected to the cod fishery. Heidenreich and Dahl examine Champlain's North American maps (2004a, pp. 321-232) and add in summary "The orientation of the map-user is always from the water to the features on the land, the direction Champlain faced in his surveys" (2004b, p. 372). As was typical of the time, Champlain's give little detailed information about the interior of the land and inland lakes, and the names assigned appear on the coastal area of Cape Breton. His 1632 map has eleven names as listed in Table $1 .{ }^{5}$

Five are boundary markers: in the north are $I . S^{t}$ Paul and $C . S^{t}$ Laurens; in the east is Cap breton; in the southeast corner is Cap $S^{t}$ Antoine; and the southern strait separating the island from mainland is the Passage de Canceau. Cap Enfumé identifies the landmark known today as Cape Smokey, just south of Ingonish on the northeast coast. This landmark is recorded frequently on early maps with names indicating smoke such as Fundos, Fumdos, Fumides, and Fumos (Ganong 1964, p. 57). Because of the distinctive white stone that runs up the face of the 280-meter cape, this landmark reminded navigators of rising columns of smoke: a welcome sight for early mariners finding their way from Europe.

\footnotetext{
${ }_{5}^{4}$ On modern maps, the orientation of these features would be to the geographic north.

${ }^{5}$ Biggar's edition of Samuel de Champlain's Works (1936) provides maps that accompanied the 1613 and 1632 publications, as well as the 1612 map (in the portfolio): "Carte Geographiqve de la Novvelle Franse faictte par le Sievr de Champlain Saint Tongois Cappitaine Ordinaire povr le Roy en la Marine, faict len 1612." It is the "most skillfully engraved of Champlain's maps" (Heidenreich and Dahl 2004a, p. 314) and has more toponyms for Cape Breton Island than the 1613 state published in Champlain's Les Voyages 1613, and so the 1612 map is discussed here. All four names on this map are along the Atlantic coast: three are boundary markers $\left(c . s^{t}\right.$ loran [Lawrence], $s^{t}$ pol [Island], and c. breton), and the fourth, niganis (now Ingonish), designates a sheltered harbour north of Cape Smokey. Heidenreich and Dahl (2004a, p. 317) point out that there are three states of Champlain's 1632 map, two of which are relevant to the mapping of Cape Breton Island. The printer prepared state one, and Champlain made corrections to state two, especially to the Ottawa River and Cape Breton Island. As a result, some editions of Champlain's Voyages were published with state one, others with state two. Both states of the 1632 map represent the coastline of Cape Breton Island vaguely and both states misrepresent the Bras d'Or Lake. State one incorrectly has one channel (instead of two) from the Bras d'Or Lake and places the channel inaccurately above Cape Smokey; state two, corrected by Champlain, accurately depicts two channels from the Bras d'Or Lake (with Boularderie Island separating the channels), but these channels are placed too far south and replace the large water features of Sydney Harbour and Glace Bay. When the engraver tipped in the revised copper insert of Cape Breton Island into state 2, the placement of names did not line up with the features named. The place names are identical in both states, but only state one has a flag indicating a French settlement at Gransibou. Biggar reproduces state one in his edition of Champlain's works (1936, vol. 6). Morissonneau (2004) discusses Champlain's place names as "appropriations" of Aboriginal lands for France, and Heidenreich and Dahl conclude: "In fact, Champlain felt that his explorations and maps laid the claim for the king of France to North America as far south as $40^{\circ}$ north latitude (Champlain [1632] in Biggar (ed.), 6, pp. 188-189). The maps, especially, were regarded by Champlain as conclusive proof that these lands had been seen and described by the French before any Dutch or English" (2004a, p. 331). As control of Cape Breton Island shifted from France to Great Britain during the eighteenth century, the assignment of names on the island varied greatly as first France and then Great Britain laid claim to the island by assigning commemorative names (Davey, 2006).
} 
Table 1: Names on Champlain's 1632 Map of Cape Breton Island.

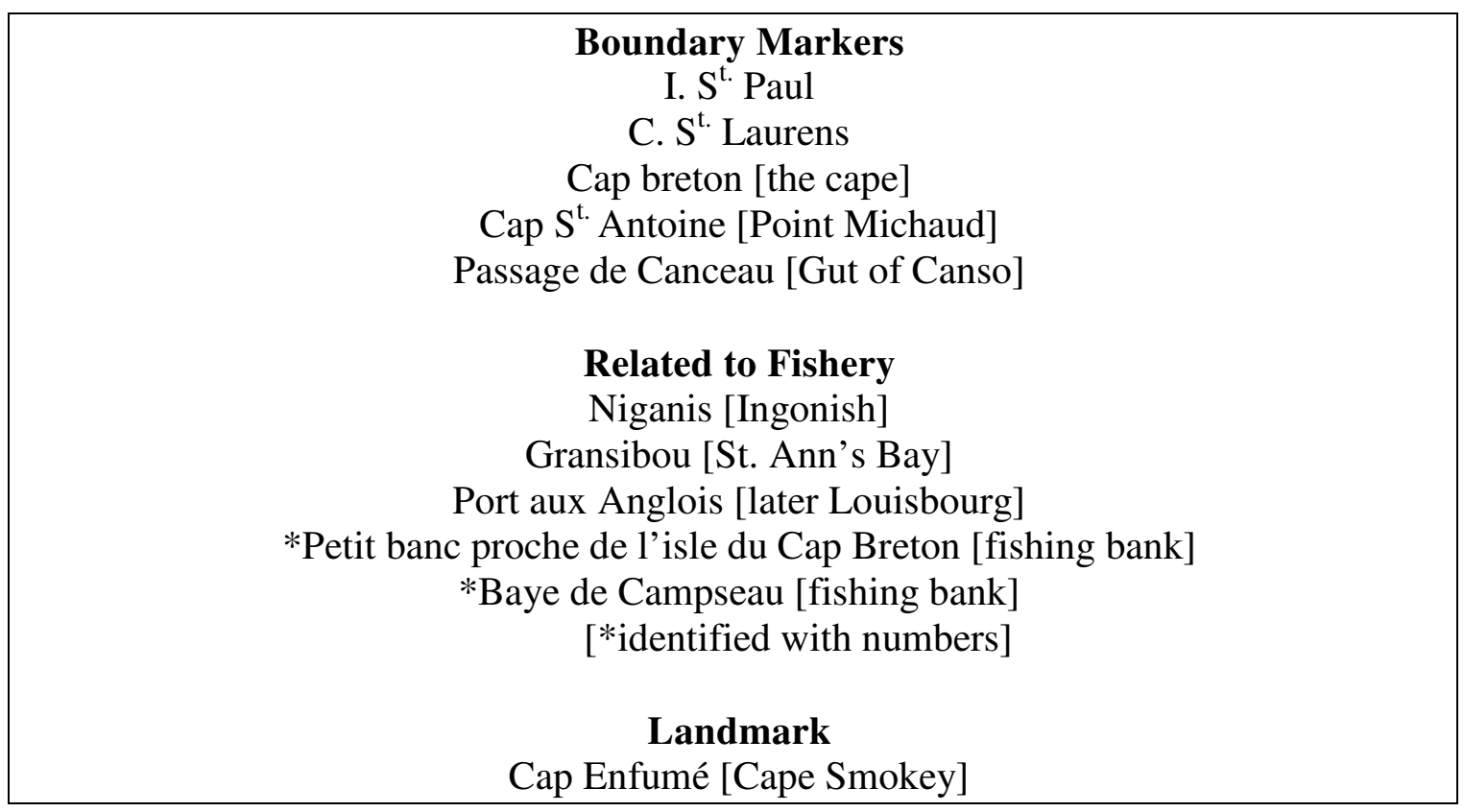

Four other names reflect the importance of the fishery. Niganis (now Ingonish) offers good fishing nearby, an accessible beach for drying fish, and a harbour sheltered by an island. Port aux Anglois (later Louisbourg Harbour) proclaims the English presence in this harbour for the seasonal fishery. Numbers designate two other water features that indicate fishing grounds: the descriptive note Petit banc proche de l'isle du Cap Breton marks a fishing bank south of Isle Madame, and Baye de Campseau (now St. Georges Bay) is the only name on the west side of the island (see numbers 27 and 32 in Champlain, 1936, vol. 6, pp. 233-234). Although Champlain does not place a name on the island, the phrase l'isle du Cap Breton indicates, in an understated fashion, that the cape and island are known as Cap Breton. The eleventh name, Gransibou, which some have interpreted as "big river or bay with a river" (Pacifique, 1934, p. 253), probably designates what is today St. Anns Bay. ${ }^{6}$ The bay has a prominent river (North River), a

${ }^{6}$ As discussed in note 5, Champlain's 1632 map of Cape Breton Island exists in two states. The exact location of Gransibou, however, is not clear on either state of the 1632 map. State one (the printer's version) uses a flag to mark a French settlement at what appears to be the current Sydney Harbour, but the map is imprecise. Ganong notes that the engravers of Champlain's map were responsible for "many lapses of evident carelessness on matters on which Champlain was well informed" (in Champlain, 1936, vol. 6, p. 222). State two (corrected by Champlain) does not have the flag to mark Gransibou, and the names are not aligned with the features being named. On the other hand, the flag indicating a settlement at Gransibou on state one argues for St. Anns Harbour as the probable location as Captain Charles Daniel of Dieppe built a French fort there in 1629 (Clark, 1968, p. 84; Morgan, 2008, pp. 24-25). Champlain learned of the settlement at Saint Anns in late 1629 from Captain Daniel when they met in Dieppe (Champlain 1936, vol. 6, pp. 150-151). Daniel's own account, published later, recounts his capturing of the English fort at Baleine on the east coast of Cape Breton and the construction of a French fort at the mouth of the harbour that Daniel calls "riuiere du grand Cibou" (reprinted in Champlain, 1936, vol. 6, pp. 159-160). Later in the century Nicolas Denys recorded Haure de $S^{\text {te }}$ Anne on his map of 1672, but his Description of North America adds "le grand Chibou, qui est l'entrée du Havre de Sainte Anne" (1908, p. 492). William Ganong notes in his edition of Nicolas Denys" Description of North America that cibou "is undoubtedly Micmac 
rocky bar that shelters anchored boats, and a rocky "beach" useful for drying fish. On state one of the 1632 map, a flag appears in the bay, to indicate "habitations qu' ont faict les françois" and probably identifies the short-lived settlement of Captain Charles Daniel of Dieppe (Champlain, 1936, vol. 6, pp. 150-151). Thus, all eleven names on the map are valuable for navigation and the fishery, with most of the names on the Atlantic coast near to the cod fishery.

\section{Eighteenth Century}

The international fishery along the coasts of Cape Breton Island ended as a result of the Treaty of Utrecht in 1713, which left France with Cape Breton Island, Isle St. Jean (later Prince Edward Island), and territory along the St. Lawrence River to the Great Lakes (Bumstead, 2011, pp. 63-68). Permanent settlement on Cape Breton increased from only six European residents according to the 1687-88 Gargus census to about 2,000 to 4,000 during the French colonial period (Clark, 1968, pp. 267-268). As part of their colonial plan, France built Fortresse Louisbourg to protect their colonies along the St. Lawrence River, but also to create a base on Cape Breton Island to claim a portion of the Atlantic cod fishery. The dry fishery required coastal areas so the land crews could split, salt, dry, and store their catch for export (Balcom, 1984). Like most of the cannons at Fortresse Louisbourg, France's attention was directed towards the sea. Their goals of colonization and exploitation of the fishery led to improved mapping and naming of the island's coasts and the Bras d'Or Lake, the island's large inland sea.

One of the most famous maps from the French colonial period is Nicolas Bellin's 1744 Carte de l'Isle Royale. As Ingenieur de la Marine, Bellin gathered cartographic information in Paris to make a composite map that was frequently reissued by the French and often adapted by other countries, including England. ${ }^{7}$ His map has over eighty

Indian, meaning "river" (in Denys 1908, p. 182). Father Pacifique adds: "To the Whites they [the Mi'kmaq] gave the name Sipo, pronounced and spelled by the French Cibou or Chibou, and Grand Cibou. This is a common name for river or a bay ending by a river or brook. The same name applied to Sydney harbour" (1934, p. 253). The earliest known record of Cibou comes from the 1597 voyage of Englishman Charles Leigh to Newfoundland and Cape Breton as he locates Cibou in relation to the island of Port Nova: "And the fift[h of July] we cast anker in a reasonable good harborow called New Port [now Port Nova] under an Island some eight leagues from Cibo, and within three leagues from the English port [the current Louisbourg]" (in Hakluyt, 1962, vol. 6, p. 107). Leigh's calculation of the distance between Port Nova and Louisbourg is accurate (allowing approximately three miles or $4.8 \mathrm{kms}$ per league, a measure of distance that varied from country to country). If his estimate of the eight leagues to Cibou is also correct, this calculation would make Sydney Harbour the likely location for Cibou, one that Cape Breton historian Robert J. Morgan accepts (2008, p. 17). If sipo / Cibou / Chibou does indicate a "river or bay ending by a river or brook" as Pacifique states, then the term is a generic that could apply to both possible locations, with Gran $(d)$ sibou referring to St. Anns Harbour and Cibo(u) to Sydney Harbour as both are bays with rivers flowing into them. The spelling of the prefix gran-suggests a Spanish or Basque origin; research by several scholars outlines the early presence of the Basque in Atlantic Canada (Barkam, 1985; Engaña Goya, 1992, pp. 54-55; Rayburn, 1994; Weyers, 2009). The spelling of grand reflects French orthography.

${ }^{7}$ For instance, after the fall of Louisbourg in 1745, Bellin's map of Cape Breton was adapted in the London Magazine of July, 1747, with the title: "A MAP of ROYAL or CAPE BRETON I. from the Best Authorities By Tho: Kitchin Geog.” (1747, pp. 304 et seq.). Walter K. Morrison (1982, p. 28) points out that Bellin's "Carte de la Partie Orientale de la Nouvelle France ou du Canada" (1744), which presents Eastern Canada, Quebec, and parts of the northeastern states, was also adapted by several British cartographers. Kenneth Kershaw (1997, vol. 3, pp. 177-187) reproduces several of these adaptations. 
toponymns in total, including nine names having alternative designations, eleven Mi'kmaw names, and indications of navigational hazards. The most dramatic change in French naming was the renaming the island as Isle Royale in 1713 (Pichon, 1760, p. 5) and the removal of the name Cape Breton from the easternmost cape. English Harbour was also renamed. With typical thoroughness, Bellin's map records both the early and current names for the harbour with Havre a [sic] l'Anglois auj. Louisbourg.

Bellin's map presents a view from the sea in three ways: the distribution or placement of the names, the types of names assigned, and the number of shift names. The majority of the names (57\%) appear on the east coast near the Atlantic fishery. Second, almost all the names are hydronyms for bays, rivers, harbours, and ports, as well as coastal features like capes, islands, and points. Many of these are the boundary markers with Cap S. Laurent and Cap de Nord in the north, and Champlain's Passage de Canseau is replaced with the commemorative name Passage de Fronsac. ${ }^{8}$ The distinctive landmark for the current Cape Smokey is Cap fumé. The map also warns mariners of the hazards like Roches sous l'eau and Basse ou Roches des basques.

Third are the shift names. Bellin's map provides no visual indication of communities, but other historical maps and documents indicate that many of the names for water features also designate villages on their shores and on some of the islands. One of these sources of cartographic evidence is an anonymous 1751 map that shows various settlements along the coasts. For instance, the cartographer shows the locations of the fortress and buildings around Louisbourg Harbour and indicates other coastal settlements. ${ }^{9}$ Table 2 is a selection of such water features where communities are marked.

All of these are shift names as the names used for the water or coastal features also serve as the community names. The names in square brackets following the map names are the current names for communities. Many of these current community names are also shift names themselves, often for coastal features such as Cape Dauphin, Alder Point, South Bar, North West Arm, and Simons Point, so this tendency towards shift names has continued over the centuries.

Writing in the 1750s, Thomas Pichon, the famous Frenchman who spied for the English, gives insight into how these early French settlements developed,

This island lay desert[ed] and uncultivated till the year 1714, when the French of Newfoundland and Acadia, made some settlements on it. They took up their quarters near the sea-shore, where there are villages containing a few scattered houses. Each person built according to his fancy, and just as he found proper ground for drying of cod-fish, and for planting of gardens. This irregular manner of building occasions a dispersion of the inhabitants, with the inconveniences arising from thence (1760, p. 2).

\footnotetext{
8 At "Canso, Strait of" Alan Rayburn states: "This narrow passage between the mainland and Cape Breton Island was called Passage de Fronsac and Détroit de Fronsac by the French between the 1660s and the 1750s after a title of an uncle and a son of Acadian Gov. Nicolas Denys (c.1598-1688), and also of Cardinal Richelieu" (2010, p. 44).

${ }^{9}$ The detail of settlements on the 1751 map indicates the cartographer's first-hand knowledge of the island. The map also depicts four roads not found on Bellin's map.
} 
Table 2: Community shift names from PLAN DE L'JSLE ROYALLE 1751.

\begin{tabular}{|c|}
\hline Ile de Niganiche [Ingonish Island] \\
Port Dauphin [Englishtown, in St. Anns Bay] \\
Entree de la Grande Brador [Cape Dauphin] \\
Entree de la petite brador [Alder Point] \\
Baye des Espagnols [South Bar] \\
bras du oüst [North West Arm of Sydney Harbour] \\
bras du Sud [South Arm of Sydney Harbour] \\
Entree de la Riuiere de Miré [Mira Gut] \\
Riuiere de Miré [Hillside] \\
Barachoix de la Miré [Catalone Road] \\
Passage de Menadou [Main-a-dieu] \\
La Baleine [Baleine] \\
Petit Laurembec [Little Lorraine] \\
Louisbourg [Louisbourg Harbour] \\
Pt. Platte [Simons Point] \\
Fort Toulouse [St. Peter's]
\end{tabular}

Given this haphazard coastal settlement, the new colonists just adopted the names already assigned to the water and coastal features. Even the two largest towns of Louisbourg and Port Toulouse (St. Peter's), where half the island population lived, are shift names, applied to both water features and communities. ${ }^{10}$ Thus, colonial interests, the fishery, and convenience of settlement contributed to this view from the sea during the French colonial period.

While the French cartography of Cape Breton Island made great advances during the early $18^{\text {th }}$ century, British surveyors Samuel Holland and J. F. W. DesBarres also made important cartographic and toponymic contributions during the last four decades of the $18^{\text {th }}$ century. As Hornsby $(2011$, p. 5) remarks, "The surveys were done using the latest scientific techniques and equipment and to the highest possible standards; in today's parlance, the surveys were 'big science"'. Since I have written about their toponymic contributions previously (Davey, 1995; 2004; 2006), this paper does not consider their work in detail. From the perspective of this paper, however, their plans and charts continue a view from the sea similar to the one found on Bellin's maps. They concentrate, like Bellin, on perimeter naming of the coastlines and waterways. Unlike Bellin's 1744 map, Holland's "A Plan of the Island of Cape Britain" (1767) and

\footnotetext{
${ }^{10}$ Thomas Pichon's Genuine Letters ... gives an account of the founding of the French colony on Cape Breton Island and then describes the various coastal settlements and their potential for development. $\mathrm{He}$ writes that in 1714, the French court was induced "to plant the colony of Cape Breton and to build the harbour Louisbourg" (1760, p. 5) and that the fortress was fortified in 1720 (1760, p. 9). The French maps indicate the evolution of the name change from English Harbour: "Havre aux Anglois was changed first to Port St. Louis (L'Hermitte's map of 1713), and then to Louis Bourg (Bourdueon's map of 1714) and Louisbourg (Mechin and Bourdon's map of 1714)" (see Davey, 1993, p. 19). The long standing name San Pedro / St. Peters became Fort Toulouse and Port Toulouse, both sharing the commemorative name of the Comte de Toulouse, a son of Louis XIV.
} 
DesBarres' The Atlantic Neptune (1773-1784) are charts rather than maps, providing hydrographic information for the channels and coastal areas as a navigational aid. ${ }^{11}$

\section{Nineteenth Century}

Cape Breton's life as a French colony ended with the second fall of Louisbourg in 1758. Under eighteenth-century conventions of war, the British forces expelled the French inhabitants, many of whom returned to France, but others hid from the British, later resettling in places like Isle Madame and Chéticamp (Morgan, 2008, pp. 55; 108-09). The 1763 Treaty of Paris ceded all of eastern Canada to Great Britain with the exception of St. Pierre and Miquelon, two small islands south of Newfoundland. The map contained in Thomas C. Haliburton's two volume Historical and Statistical Account of Nova-Scotia (hereafter Historical Account) illustrates the toponymy 66 years into the British colonial period. This influential book went through four editions between 1829 and 1844, and Haliburton received a formal commendation from the Nova Scotia House of Assembly for his book. Although the map in Haliburton's Historical Account is anonymous, Walter $\mathrm{K}$. Morrison has argued that William MacKay was the cartographer and comments ". . . the 1829 map model persisted and influenced atlas maps for the rest of the century" (1982, p. 33).

By 1829 the landmarks and boundary markers have become standard on maps of Cape Breton. The names Cape Breton and the GUT OF CANSEAU, missing on Bellin's map, are restored, and most of the prominent capes and coves on the eastern side are named as an aid to mariners. The distribution of the 135 names on the map also reveals a view from the sea. Like Bellin's map, most of the names continue to appear on the east coast where the harbours offer shelter and access to the inshore and bank fisheries. Unlike Bellin's map, the number of names have increased both on the western side of the island and on the Bras d'Or Lake because of the growing population in those areas. As D. C. Harvey and more recently Stephen Hornsby have stated, the population of the island spiked from about 2,513 in 1802 (Harvey, 1941, p. 315) to nearly 19,000 by 1830 (Hornsby 1992, p. 48). Most of these settlers arrived from the Scottish Highlands and Western Islands, and the immigration continued until the mid 1840s. Many of the new immigrants settled in coastal communities like Fourchu and Framboise formerly used by the French. Others sought land grants along the Bras d'Or Lake, the western side of the island, and the fertile river valleys so they could fish and farm as they did in Scotland. These prime lots, called "frontlands," had fertile land and access to the water for fishing and transportation by boat as few roads were available. The 1829 map has about twelve roads, most of which are short and either follow the shores or run between two bodies of water. Table 3 lists the shift names according to water or coastal features.

\footnotetext{
${ }^{11}$ Walter Morrison (1990) provides a visual guide of the fifteen charts of Cape Breton in The Atlantic Neptune. Hornsby's Surveyors of Empire: Samuel Holland, J.W.F. Des Barres, and the making of the Atlantic Neptune (2011) presents a thorough analysis of the surveyors' progress, working relationship, and remarkable accomplishments in mapping eastern Canada.
} 
Table 3: Shift names of communities on Haliburton's Historical Account, 1829 Map.

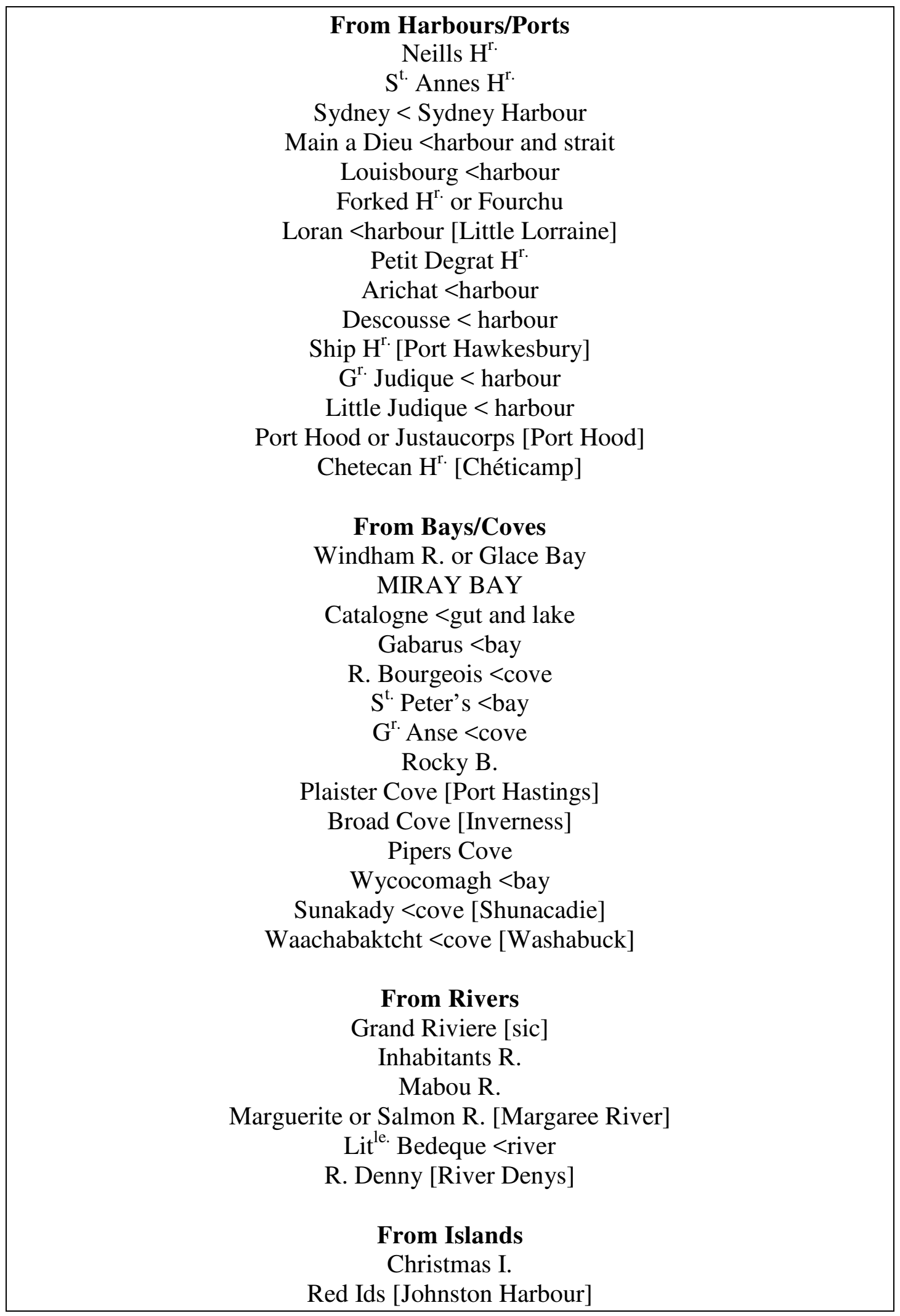


The first two groups - harbours and bays - are the most productive sources of shift names. Despite the British colonial rule for over sixty years, most of the shift names on the east coast are derived from those assigned during the French regime. The British immigrants took over the former French fishing villages and retained the earlier names like $S^{t}$ Annes, Judique, Catalogne, R. Bourgeois, Inhabitants $R$., etc. With the French fortress at Louisbourg destroyed by order of William Pitt, the once thriving port was resettled as a small fishing community. The Robins Company from the Channel Islands took over the fishing stations in Arichat and Chéticamp and employed mostly French fishers. Other shift names like Sydney, Piper's Cove, and Red Islands reflect the British presence. The main exception to this emphasis on fishing was the new community of Sydney. J. F. W. DesBarres, the first governor of Cape Breton, applied the name Sydney to the harbour and then later to the colony's capital. ${ }^{12}$ Although many fishers used Sydney Harbour and North Sydney as their home port, the town of Sydney was more of an administrative and military centre than a fishing port.

The six river names that shifted to settlements were for the most part navigable rivers where settlers could farm and fish. The two settlements named after islands, Christmas I. and the Red Ids, illustrate a pattern where mariners first used the islands as landmarks and then the name was later applied to the communities on the shores nearby.

The final exemplar is from the Atlas of the Maritime Provinces, published in 1878 by Roe Brothers of Saint John, NB. ${ }^{13}$ The previous maps discussed are single sheet maps, whereas an atlas collects several maps into a single book. This atlas contains county maps of the three Maritime Provinces, along with an insert of the then-colony of Newfoundland, two regional maps, and some city maps. As Joan Dawson explains in her introduction to a new edition of the 1878 Atlas, county maps were popular in England during the eighteenth and nineteenth centuries, adding,

The fashion spread to Canada in the later nineteenth century, when commercial publishers in the Maritime Provinces began to produce large-scale sheets of individual counties (Dawson, 2005, p. 7).

The Atlas draws on this interest, using a scale of seven miles to one inch for the county maps, and has essays on history and geology as part of the introduction. The interest in history is also seen in several toponyms that have alternate names, one current and one historical.

The Atlas illustrates the many changes on Cape Breton Island since Haliburton's 1829 Historical Account. As Hornsby notes, the Census of Canada 1870-71 indicates that the population of the island was 75,000, most of whom were born in Cape Breton (1992,

\footnotetext{
${ }^{12}$ Rayburn notes that J. F. W. DesBarres assigned the name Sydney Harbour in 1784-5 "after Thomas Townshend, $1^{\text {st }}$ Viscount Sydney (1733-1800), British home secretary, 1782-1789, Lord of the Admiralty, 1790-1793, and Lord of the Treasury, 1793-1800" (2010, p. 288). DesBarres spent his first winter as governor of Cape Breton on Point Edward, the peninsula that divides the northwest and south arms of Sydney Harbour, before moving across the harbour in the spring to found Sydney in its present location.

${ }^{13}$ The full title of the 1878 edition is the Atlas of the Maritime Provinces of the Dominion of Canada, with historical and geological descriptions (abbreviated hereafter to the Atlas). A new edition of the Atlas published in 2005 is titled Historical atlas of the Maritime Provinces (Roe, 2005). This new edition reproduces all the maps and introductory essays of the original, but also has a useful introduction and captions written by Dawson.
} 
p. 121). As a result of the increased population, the improved techniques of surveying and map making, and the large scale of the country maps, the Atlas records over 340 names in the four Cape Breton counties: 100 in Cape Breton County, 94 in Inverness County, 75 in Richmond County, and 77 in Victoria County. As Dawson points out, the Atlas has a number of errors in copying from source maps (2005, p. 7). In the Cape Breton Island maps, for example, Schooner Cove appears as Spooner Cove, the township name SYDNEY appears without the first three letters, and some names are misplaced. However, the typographical challenges in creating the maps are considerable: the widely different sizes of fonts, use of italics for water ways and roman type for other features, and block capitals for features like mountain ranges, townships, county names, and large bodies of water. The Atlas also reflects the improved transportation by land with the increased number of roads and the railroad between Louisbourg and Sydney. A projected rail line from Port Hawkesbury to Louisburg is also recorded, although its route was later altered. There are also signs of industrialization with several mining communities named in the Cape Breton County and the MIDDLE RIVER GOLD MINES in the BADDECK HILLS. Despite these changes, Cape Breton Island, like the rest of the Maritime Provinces at this time, remained rural (McInnis and Usher, 1993, Plate 5) with forestry, farming and fishing being main contributors to the economy. ${ }^{14}$

Like the 1829 map in Haliburton's Historical Account, the assignment of names to standard boundary markers, landmarks, and prominent capes and points indicates the view from the sea. There is an increase in names in the Bras d'Or Lake area, on the west side of the island, and along the tributaries of the Margaree, Mabou, and Middle rivers. What is remarkable, however, is the large number of community shift names as Table 4 indicates.

\section{Table 4: Distribution of community names by county}

\begin{tabular}{|lccc|}
\hline County & Shift Names & Other Comm. Names & Total Comm. Names \\
\hline & & & \\
\hline Cape Breton & 33 & 11 & 44 \\
\hline Inverness & 42 & 8 & 50 \\
\hline Richmond & 20 & 6 & 26 \\
\hline Victoria & $\underline{33}$ & $\underline{4}$ & $\underline{37}$ \\
\hline Totals & $\mathbf{1 2 8}$ & $\mathbf{2 9}$ & $\mathbf{1 5 7}$ \\
\hline
\end{tabular}

The shift names for communities account for $81.5 \%$ of the total community names recorded in the four counties. The percentage of shift names in each county varies from the mid-70s in Cape Breton (75\%) and Richmond (77\%) counties to the 80 s in Inverness $(84 \%)$ and Victoria $(89 \%)$ counties. Table 5 provides a closer look at the shift names shared by communities and other features.

14 Duncan Campbell's introductory essay in the Atlas reports that the top source of exports from the Maritime Provinces varied: forestry in New Brunswick; fishery in Nova Scotia; agriculture in Prince Edward Island. Manufactured exports were low in all three provinces (Campbell in Roe, 1878, pp. 5-8). 
Table 5: Classification of community shift names by county.

\begin{tabular}{|lccccc|}
\hline Feature & Cape Breton & Inverness & Richmond & Victoria & Totals \\
\hline Water & 28 & 36 & 13 & 22 & 99 \\
\hline Coastal & 2 & 4 & -- & 7 & 13 \\
\hline Bridges & 2 & 1 & -- & 2 & 5 \\
\hline Ferries & -- & -- & 3 & -- & 3 \\
\hline Geological & -- & 1 & -- & 2 & 3 \\
\hline Islands & 1 & -- & 2 & -- & 3 \\
\hline Roads & -- & -- & $\underline{2}$ & -- & $\underline{2}$ \\
\hline Totals & $\mathbf{3 3}$ & $\mathbf{4 2}$ & $\mathbf{2 0}$ & $\mathbf{3 3}$ & $\mathbf{1 2 8}$ \\
\hline
\end{tabular}

Water and coastal features are still the most productive sources and account for $87.5 \%$ of the total community shift names. The water features identify harbours, bays, coves, rivers and lakes; and the coastal features denote points, bars, and heads. Other shift names are derived from ferry crossings and bridges. As Dawson points out, waterways were important in all the Maritime Provinces for the fishery and transportation, but rivers and long harbours also created "formidable barriers, and required ferries and bridges to link communities on opposing banks" (2005, p. 7). Ferry crossings became meeting places as travellers and neighbours would gather there, and frequently small communities grew around them. In some instances, bridges later replaced the ferries and the communities survived. This was the history of Marion Bridge and Albert Bridge, which span the Mira River. ${ }^{15}$ Other ferry crossings with associated communities persisted well into the twentieth century. This is the situation with the communities of Grandique Ferry and Lennox Ferry on opposite sides of Lennox Passage that separates mainland Cape Breton from Isle Madame. Similarly, the community of $M^{c}$ Phersons Ferry marked the landing and launching point on Cape Breton for the ferries between mainland Nova Scotia and Cape Breton in 1878. Islands also contributed to the community shift names. Mariners first used Christmas Id, Red Id. and Cheticamp Id. as navigational aids, and later the communities that grew on the island's shores used those names for the communities.

Thus, all but 5 of the 128 community shift names are associated with water in some way. Of the remaining names, 3 are derived from geographic features: Marble $M^{t}$, Hunters $M^{t}$, and the river valley Big Intervale. This leaves two small Richmond County communities with their names derived from crossroads, Kempt $R^{d .}$ and Cross Roads. ${ }^{16}$

Because of this frequent use of shift names, several groups of names with a similar specific developed. George Stewart calls these "name clusters" (1970, p. xxxi). Each county has at least one group, or cluster, that has five or more shift names with the same specific. In Cape Breton County, the administrative centre Sydney has six names in which Sydney is used, and the Mira River area also has six names, two for water features and four for communities. A similar pattern exists in Victoria County, where the

\footnotetext{
15 Dawson reports a similar history in Pictou County for the communities of Springhill, Churchville and Hopewell (2007, p. 127).

16 The name Riv. Dennis Road in Richmond County is a hybrid that has been considered as a shift name from a water feature but might also be seen as deriving from a crossroad.
} 
administrative centre Baddeck has eight associative names, and Middle River has five names for water features and communities along the river's banks. In Richmond County, St. Peters appears in six names close to this historic community, one of the earliest names recorded on the island. In Inverness County the three largest groups of shift names are related to rivers. Various forms of River Dennis are found in five names, and the many branches of the Mabou and Margaree rivers have generated the most names - nine with Mabou and eleven with Margaree - most of which are for small communities on the various tributaries. Finally, the Bras d'Or, which borders parts of all four counties, is also prolific as it is found in seven names for waterways and communities. Name clusters of three or four names are even more numerous than those mentioned above.

Clearly, shift names recorded in the Atlas are a distinctive trend of the toponymy of Cape Breton Island.

\section{Conclusion}

The maps discussed present an evolving picture of how a view from the sea has contributed to the toponymy of Cape Breton Island. This influence is evident in the assignment of names along the coasts, the early and persistent naming of boundary markers and coastal landmarks, and the increasing number of shift names. Like other cartographers of his time, Champlain had difficulty recording longitude accurately, but his 1632 map is mariner friendly with names for landmarks, boundary markers, and harbours near productive fisheries. Bellin's 1744 map establishes a template for future shift names on the island as settlements grew in many of the sheltered harbours and areas with beaches and shores suitable for processing fish. The two nineteenth-century maps continue the naming patterns of the French cartographers. The east coast names continue to be most numerous, but gradually settlement along the shores of the Bras d'Or Lake region and the west side of the island account for increased numbers of shift names. On the four Cape Breton county maps in the Atlas of the Maritime Provinces, shift names account for a little over $80 \%$ of the community names, most of which are derived from water features, with others coming from bridges, ferry crossings, and roads.

The view from the sea is also preserved in the ethnic diversity of the names on the island. In Richmond County alone, these include Arichat, a name derived from Mi'kmaq meaning "worn or shivered rocks" (Morgan, 2008, p. 11), and several French names such as Fourchu (for the forked-shaped harbour) and Grand Anse (Big Cove). Several English commemorative names - including Richmond County itself, Port Richmond and Lennox Ferry - are named for the Fourth Duke of Richmond and Lennox. ${ }^{17}$ Kempt $R^{d .}$ commemorates a Nova Scotia lieutenant-governor, and toponyms like $S^{t}$ Esprit and St. Georges Chanl are not only religious commemoratives but also acknowledge the French and English colonial presence on Cape Breton. Elsewhere on the island, other nationalities are memorialized with names like C. Basque, Kilkenny L., and INVERNESS.

Perimeter naming along the seacoasts and shores of rivers is a pattern found in all the Atlantic Provinces as transportation was easiest by boat because roads were slow to

\footnotetext{
${ }^{17}$ Many of the commemorative names on Isle Madame honour Charles Lennox, $3^{\text {rd }}$ Duke of Richmond and Lennox, Earl of March, Earl of Darnley, and duc d'Aubiny. These derive from Samuel Holland's 1767 "Plan of the Island of Cape Britain" where he assigns 21 of 28 names on Isle Madame to Lennox and his family (Davey, 2006, pp. 9-10).
} 
develop. Coastal settlement has resulted in many shift names. Mainland Nova Scotia's River John is both a river and a village; New Brunswick's Saint John and Newfoundland's Ferryland, Joe Batt's Arm and St. John's were initially named as water or coastal features before becoming community names (Rayburn, 2010). The Cape Breton naming pattern is not unique, but it is a distinctive, regional feature shared in the Atlantic Provinces. Despite this general pattern, it is remarkable that over $80 \%$ of the communities in the four Cape Breton counties have shift names and that all but a few of these share names with water features.

\section{References}

Balcom, B. A. (1984). The cod fishery of Isle Royale, 1713-58. Ottawa ON: Parks Canada, National Historic Parks and Sites Branch.

Barkam, S. H. (1985). Fishermen's contribution to the early cartography of Eastern Canada. In Eleventh International Conference on the History of Cartography, 1812 July 1985, (pp. 1-9). Ottawa ON: National Map Collection, Public Archives of Canada.

Bumstead. J. M. (2011). A history of the Canadian peoples. Don Mills ON: Oxford University Press.

Champlain, Samuel de. (1936). The works of Samuel de Champlain in six volumes. Edited by H. P. Biggar, W. D. LeSuer \& H. H. Langton (Trans.). Toronto ON: Champlain Society. Reprinted 1971. Toronto ON: University of Toronto Press.

Clark, A. H. (1968). Acadia: The geography of early Nova Scotia to 1760. Madison WI: University of Wisconsin Press.

Davey, W. (2006). Eighteenth-century Cape Breton island and the politics of naming. Onomastica Canadiana 88(1), 1-18.

Davey, W. (2004). DesBarres' reliance on Holland's "Plan of the Island of Cape Britain" and the Beaton Institute's Chart 667. Journal of the Royal Nova Scotia Historical Society 7, 140-158.

Davey, W. (1995). European naming patterns on Cape Breton Island 1758-1820. Onomastica Canadiana 77(1), 35-59.

Davey, W. (1993). European naming patterns on Cape Breton Island: the early period. Onomastica Canadiana 75(1), 11-26.

Dawson, J. (2007). The map makers' legacy: Nineteenth-Century Nova Scotia through maps. Halifax NS: Nimbus Publishing.

Dawson, J. (2005). Introduction. In Historical atlas of the Maritime Provinces. (pp. 4-8). Halifax NS: Nimbus Publishing.

Dawson, J. (1988). The mapmaker's eye: Nova Scotia through early maps. Halifax NS: Nimbus Publishing and the Nova Scotia Museum.

Denys, N. (1908). The description and natural history of the coasts of North America (Acadia). Translated and edited by W. F. Ganong. Toronto ON: Champlain Society. Reprinted 1968. New York: Greenwood Press.

Donovan, K. (1984). The Marquis de Chabert and the Louisbourg observatory in the 1750s. The American Neptune 44(3), 186-197.

Engaña Goya, M. (1992). Basque toponymy in Canada. Onomastica Canadiana 74(2), 54-55. 
Fischer, D. H. (2008). Champlain's Dream. New York: Alfred A. Knopf Canada.

Ganong, W. F. (1964). Crucial maps in the early cartography and place-nomenclature of the Atlantic coast. Introduction, commentary, and map notes by T. E. Layng. Toronto ON: University of Toronto Press.

Hakluyt, R. (1907, rpt. 1962). The voyage of M. Charles Leigh, and divers others to Cape Briton and the isle of Ramea. In The principal navigations, voyages, traffiques \& discoveries of the English nation (pp. 100-114). vol. 6. London: Dent.

Haliburton, T. C. (1829). An historical and statistical account of Nova-Scotia in two volumes. Halifax NS: Joseph Howe.

Harvey, D. C. (1941). Scottish immigration to Cape Breton. Dalhousie Review 21(3), 313-24.

Heidenreich, C. E., and Dahl, E. H. (2004a). Samuel de Champlain's cartography, 16031632. In R. Litalien \& D. Vaugeois (Eds.), Champlain: The birth of French America (pp. 312-332). Translated by K. Roth. Montreal QC: McGill-Queen's University Press.

Heidenreich, C. E., and Dahl, E. H. (2004b). A commentary on Champlain's surviving cartography, 1603-1632. In R. Litalien \& D. Vaugeois (Eds.), Champlain: The birth of French America (pp. 372-373). Translated by K. Roth. Montreal QC: McGill-Queen's University Press.

Holland, Samuel. (1935). Holland's description of Cape Breton Island and other documents. Edited and introduced by D. C. Harvey. Halifax NS: Public Archives of Nova Scotia.

Hornsby, S. J. (1992). Nineteenth-Century Cape Breton: A historical geography. Montreal QC: McGill-Queen's University Press.

Hornsby, S. J. with cartography by Stege, H. (2011). Surveyors of Empire: Samuel Holland, J. F. W. Des Barres, and the making of The Atlantic Neptune. Carleton Library Series, Vol. 221. Montreal QC: McGill-Queen's University Press.

Kershaw, K. A. (1997). Early printed maps of Canada 1703-1799: Maps of Eastern Canada \& Newfoundland, the Maritimes, Nova Scotia, Halifax, Prince Edward Island, Sable Island, Cape Breton, Louisbourg \& the Great Lakes. vol. 3. Ancaster ON: Kershaw Publishing.

Lemon, D. P. (1987). Theatre of empire: Three Hundred Years of maps of the Maritimes / Ambitions impérialistes: Trois cents années de cartographie dans les Maritimes. Saint John NB: NBM Publications.

Lescarbot, M. (1911). The history of New France. vol. 2. Introduced by H. P. Biggar and translated by W. L. Grant. Toronto ON: Champlain Society. Reprinted 1968, Lescarbot: History of New France. vol. 2. New York: Greenwood Press.

London Magazine. (1747).

McInnis, M., and Usher, P. J. (1993). Plate 5. In R. L. Gentilcore, D. Measner \& R. Walder (Eds.), Historical Atlas of Canada: Volume II, The land transformed. Cartography and design by G. J. Matthews. Toronto ON: University of Toronto Press.

Morgan, R. J. (2008). Rise again! The story of Cape Breton Island. Book One. Sydney NS: Breton Books.

Morrison, W. K. (1990). Cape Breton maps in The Atlantic Neptune: a HollandDesBarres connection. Nova Scotia Historical Review, 10(2), 111-123. 
Morrison, W. K. (1982). The 'modern' mapping of Nova Scotia. The Map Problem, 18, 28-34.

Morrison, W. K. (1975). The other revolution in 1775. In Association of the Canadian Map Libraries: Proceedings of the Ninth Annual Conference, 15-20 June 15-20. (pp. 59-79). Sackville NB. Ottawa: Association of Canadian Map Libraries.

Morissonneau, C. (2004). Champlain's place-names. In R. Litalien \& D. Vaugeois (Eds.), Champlain: The birth of French America, translated by K. Roth (pp. 218-229). Montreal QC: McGill-Queen's University Press.

Pacifique, le P[ère]. (1934). Le pays des Micmacs. Montréal QC: La Réparations, Prés Montréal.

Pichon, Thomas. (1760). Genuine letters and memoirs, relating to the natural, civil and commercial history of the islands of Cape Breton and Saint John, from the first settlement there, to the taking of Louisbourg by the English, in 1758. By an Impartial Frenchman. London: J. Nourse.

Rayburn, A. (1973). Geographic names of Prince Edward Island. Ottawa ON: Department of Energy, Mines and Resources.

Rayburn, A. (1994). The Basque legacy on Canada's east coast. Canadian Geographic, July/August 74-75.

Rayburn, A. (1997). Place names of Ontario. Toronto ON: University of Toronto Press.

Rayburn, A. (2010). Place names of Canada. $2^{\text {nd }}$ edn. Oxford: Oxford University Press.

Roe, A. D., and Roe, W. B. (1878a). Atlas of the Maritime Provinces of the Dominion of Canada, with historical and geological descriptions. Saint John NB: Roe Brothers.

Roe, A. D., and Roe, W. B. (1878b / 2005). Historical atlas of the Maritime Provinces. Halifax NS: Nimbus Publishing.

Seary, E. R. (1971). Place Names of the Avalon Peninsula of the Island of Newfoundland. Toronto ON: University of Toronto Press. Reprinted 1993. Ann Arbor MI: UMI Books on Demand.

Stewart, G. R. (1970). Introduction. In American place-names: A concise and selective dictionary for the continental USA. New York: Oxford University Press.

Story, G. (1990). The view from the sea: Newfoundland place-naming. In J.-C. Boulanger (Ed.), Proceedings of the $16^{\text {th }}$ International Congress of Onomastic Sciences, Université de Laval, 16-29 August 1987 (pp. 41-58). Quebec City QC: Les Presses de l'Université Laval.

Story, G. M., Kirwin, W. J., and Widdowson, J. D. A. (Eds.) (1990). Dictionary of Newfoundland English: Second Edition with Supplement. Toronto ON: University of Toronto Press.

Thomson, D. W. (1966). Men and meridians: The history of surveying and mapping in Canada. Volume I: Prior to 1867. Ottawa ON: Queen's Printer.

Weyers, C. (2009). Basque traces in the toponymy of Newfoundland and various coasts of Atlantic Canada. In W. Ahrens, A. Lapierre, G. Smith, M. Figueredo \& S. Embleton (Eds.), Names in multi-lingual, multi-cultural and multi-ethnic contact: Proceedings of the 23rd International Congress of Onomastic Sciences, 17-22 August 2008 (pp. 1051-1063). Toronto ON: York University. 


\section{List and sources of maps cited}

Anon. (1751). Plan de L'Jsle Royalle 1751. Manuscript map available at the Beaton Institute, Cape Breton University, Sydney, NS. Reprinted in J. Dawson, 1988, The mapmaker's eye: Nova Scotia through early maps (p. 144). Halifax NS: Nimbus Publishing and the Nova Scotia Museum.

Bellin, N. (1744). Carte de l'Isle Royale, Dressée par N. Bellin, Ingenieur de la Marine. Manuscript map available at the Beaton Institute, Cape Breton University, Sydney, NS. Retrieved from http://gallica.bnf.fr/ark:/12148/btv1b6700121w/f1.item

Champlain, Samuel de. (1612). Carte geographiqve de la Novvelle Franse faictte par le Sievr de Champlain Saint Tongois Cappitaine Ordinaire povr le Roy en la Marine, faict len 1612. In the portfolio, Samuel de Champlain, 1936, The Works of Samuel de Champlain in Six Volumes, edited by H. P. Biggar, W. D. LeSuer and H. H. Langton (Trans.). Toronto ON: Champlain Society. Reprinted 1971. Toronto ON: University of Toronto Press. Retrieved from http://data2.collectionscanada.gc.ca/e/e097/e002419345.pdf

Champlain, Samuel de. (1632). Carte de la Nouuelle France, augmentée despuis la derniere, seruant a la nauigation faicte en son vray Meridien, par le $S^{\mathrm{r}}$ de Champlain . . . 1632." In vol. 6, Samuel de Champlain, 1936, The Works of Samuel de Champlain in Six Volumes, edited by H. P. Biggar, W. D. LeSuer and H. H. Langton (Trans.). Toronto ON: Champlain Society. Reprinted 1971. Toronto ON: University of Toronto Press. Retrieved from http://data2.archives.ca/e/e431/e010764733.pdf

Denys, Nicolas. (1908). Denys' map of l'Amerique Septentrionale. In The description and natural history of the coasts of North America (Acadia), translated and edited by W. F. Ganong (pp. 240 et seq.). Toronto ON: Champlain Society. Reprinted 1968. New York: Greenwood Press, Publishers.

Haliburton, Thomas C. (1829). A new map of Nova Scotia compiled from the latest surveys expressly for the historical \& statistical account of Nova Scotia 1929 [by William MacKay]. In An historical and statistical account of Nova-Scotia Vol. 2. Halifax NS: Joseph Howe. Retrieved from https://novascotia.ca/archives/maps/archives.asp?ID=15

Holland, Samuel. (1767). A plan of the island of Cape Britain reduced from the large survey made according to the orders and instructions of the Right Honorable the Lords Commissioners for Trade and Plantations. Manuscript map available at the William L. Clements Library, Ann Arbor MI. Retrieved from http://maps.bpl.org/id/n51791

Münster, S. (ca. 1540-1568). La table des Isles neufues, lesquelles on appellee isles d'occident \& d'Indie pour diuers regardz. In D. P. Lemon, 1987, Theatre of Empire: Three hundred years of maps of the Maritimes / Ambitions impérialistes: Trois cents années de cartographie dans les Maritimes (p. 35). Saint John NB: NBM Publications.

Roe, A. D., and Roe, W. B. (1878). County maps of Cape Breton, Richmond, Inverness and Victoria. In Atlas of the Maritime Provinces of the Dominion of Canada, with historical and geological descriptions (pp. 50-52). Saint John NB: Roe Brothers. 